\title{
Da agulha ao chip: brevíssima revisão dos estudos de recepção
}

\author{
Nilda Jacks \\ Doutora; Universidade Federal do Rio Grande do Sul \\ njacks@terra.com.br
}

\section{Resumo}

Este texto retoma a passos largos a trajetória dos estudos de recepção para apontar o caráter sempre narrativo das teorias, dependendo do ponto de vista de quem narra. São vinculações teóricas e ideológicas que resultam em modos diferentes de conceber a história do campo, com inclusões e exclusões diferenciadas de teorias e correntes, que variam de autor para autor ao longo do tempo. São indicadas nomenclaturas que entraram em vigor no campo desde que este inaugurou suas atividades nos anos iniciais do século passado, fator crítico neste momento de transição do estatuto do receptor, que em muitos momentos torna-se produtor, um receptor-produtor. Algumas críticas sobre o alcance dos estudos de recepção para entender os processos comunicacionais contemporâneos, que atingem um alto grau de complexidade, são apresentadas. 0 estudo é concluído com algumas possibilidades de enfrentamento analítico que surgem a partir da própria tradição dos estudos de recepção ancorados nos estudos culturais, com possíveis arranjos com os estudos ciberculturais.

\section{Palavras-chave}

Estudos de recepção. Teoria da comunicação. Estudos Culturais.

\section{Introdução}

Nem tão longa para estar completamente consolidada, nem tão curta que sua importância possa ser desconsiderada, a trajetória da pesquisa de recepção tem sua origem vinculada à denominada teoria da agulha hipodérmica, e suas mais recentes transformações e desafios às tecnologias informacionais, que têm no chip o elemento de sua revolução.

De forma irônica, bem humorada e criativa, o pesquisador colombiano, e crítico de TV, Omar Rincón (2008), aborda a trajetória dos estudos de recepção classificando-as da seguinte forma: as audiências conhecidas, as imaginadas, as reais e as sonhadas. No primeiro 
caso, narra o encontro com as teorias ainda como estudante de comunicação, comentando a dos efeitos, a da manipulação ideológica, a dos usos e gratificações, a do cultivo, a do receptor idealizado, entre tantas outras desenvolvidas no intervalo de pouco mais de 50 anos.

0 autor ponta que o conhecimento das duas primeiras teorias o deixava com a sensação de ser superinteligente, pois não se sentia nem manipulado, nem dominado, e que o prazer e a autonomia do receptor, defendidos pela teoria dos usos e gratificações, desfizeram as suas preocupações sobre a perversidade dos meios.

Na sequência de sua experiência como estudante das teorias, diz que

[...] mais tarde, encontrei-me com uma teoria que dizia que o assunto era de longo prazo, pois as mensagens midiáticas constroem valorações e compreensões, mas de longo prazo, e que a isso se chama cultivo de valores (Gerbner); assim, a televisão termina decidindo o que e quem é o válido, o bom, o legítimo para a sociedade, mas através de gerações. (RINCÓN, 2008, p. 94, tradução nossa).

O autor segue apontando os tensionamentos realizados pelos estudos culturais, citando Stuart Hall e David Morley, e os realizados mais tarde pelas teorias latino-americanas, uma vez que ambos davam lugar a um sujeito receptor mais complexo do que o pensado anteriormente. Isto incluía a perspectiva dos usos e gratificações, que, apesar de reconhecer o lugar do receptor, o pensava todo poderoso, ou seja, ainda tendendo a uma simplificação como as realizadas pelos estudos dos efeitos.

Sobre as teorias latino-americanas, declara que

Se começa a pensar nas audiências como sujeitos e comunidades ativas capazes de replicar as intencionalidades industriais e ideológicas dos meios; as audiências são cúmplices dos processos de dominação comunicativa, mas ao mesmo tempo resistem e replicam. Daí nasce uma corrente própria que investiga os usos populares do massivo na vida cotidiana e a revalorização das outras maneiras de ler dos sujeitos sociais. (RINCÓN, 2008, p. 94, tradução nossa).

Antes disso, porém, refere-se às reflexões de Umberto Eco que traziam um entendimento de que a televisão apenas participava da produção de estilo de vida e de modulações da linguagem, trazendo o leitor inscrito nos textos midiáticos. Comenta sobre esta perspectiva que deixava "todos tranquilos porque há leitores modelos, que entendiam, e aberrantes, que produziam significados não intencionados pelo emissor" (RINCÓN, 2008, p. 94, tradução nossa).

Sobre as "audiências que imaginou", ele discorre sobre seu processo posterior, como pesquisador, para entender melhor os meios e reconhecer sua profunda inserção na cultura e na sociedade contemporâneas, como fruto de ambas que são, portanto com intenso signifi- 
cado para suas audiências. Com os meios elas se informam, se divertem, sonham, aprendem, normatizam o cotidiano, sofrem, acompanham a narrativa do presente, o relato coletivo, a história atrás de si.

Os meios são importantes na vida das pessoas porque produzem sentido, porque fazem parte da cultura e não atuam apenas como transmissores ou produtores autônomos de significados e imaginários. Eles fazem parte de diversas instituições de significação, como a política, a família, a educação, entre outras.

Em termos das audiências, Rincón (2008, p. 96, tradução nossa), incluindo-se nelas, diz:

[...] vamos às mídias em busca de sua companhia, enquanto paisagem simbólica prioritária no cotidiano; as telas nos fazem sentir seguros porque suas mensagens nos normalizam a vida e nos fazem sentir inteligentes e importantes, pois sabemos compreender o que está passando em cada relato, podemos adivinhar o que vai suceder no próximo capítulo. Buscamos as mídias para nos entretermos e sonharmos que o amor e a justiça ainda são possíveis, vamos exercer nossa cultura emocional, e rir e suspirar com suas histórias.

Na sequência do referido artigo, o autor relata seu trabalho como crítico de TV, comentando as mensagens diárias que recebe dos receptores, as "audiências reais", especulando que as enviam por puro masoquismo ou catarse. Afirma que os receptores o aborrecem, o decepcionam porque têm dupla moral: atiram a pedra e escondem a mão, criticam os meios e não agem coerentemente, quanto mais os criticam mais expostos a eles estão. Por isto opina que:

Talvez devamos começar a aceitar que vemos televisão para odiá-la, que só nos produz prazer o que podemos criticar, que as mídias devem ser perversas para que possamos como cidadãos sentir-nos inteligentes. Talvez devamos assumir que encontramos nas telas uma desculpa que nos permite eliminar todas as nossas repressões, nossos defeitos, nossas pobrezas de espírito. (RINCÓN, 2008, p. 96, tradução nossa).

Com menos ironia e mais esperança, na última parte de sua análise, sobre as "audiências sonhadas", Rincón (2008) explora as novas possibilidades da audiência frente à interatividade proporcionada pelas tecnologias de comunicação, enfatizando o aspecto político e cidadão da relação com os meios, como forma de transformar receptores em produtores de seus próprios conteúdos. Mas não sem antes pontuar que as pesquisas sobre recepção dos meios são incapazes de gerar qualquer transformação na produção midiática, apontando que esta é a maior debilidade das pesquisas da área. 
Sugere que é preciso criar políticas e ações cidadãs para reivindicar os direitos dos receptores, e que as pesquisas da área atuem na perspectiva da cidadania, do ativismo e da política. Razão para indicar que:

\begin{abstract}
Necessitamos deixar de ser audiências e começar a ser produtores. Os setores populares e os meios necessitam que sua voz, discurso, relato e estética se façam públicos e, a partir de seus códigos, expressivos. A proposta é promover o acesso diversificado às telas; produzir interpelações novas; passar de consumidor a cidadão ao formar sujeitos para a política, trabalhar pela autoestima social e as identidades culturais, promover visibilidades, acessos e reconhecimentos novos, gerar cidadanias midiáticas ("veedurías"1, grupos de telespectadores, comunidades de sentido, observatório de meios), atender audiências minoritárias; produzir mensagens que gerem reconhecimento e identificação. (RINCÓN, 2008, p. 97, tradução nossa).
\end{abstract}

Este longo e pouco ortodoxo introito contém vários elementos interessantes para pensar as teorias como uma narrativa, a noção de audiência e de receptores como uma construção histórica, e as transformações internas e externas ao campo acadêmico pautando a dinâmica da pesquisa e da teoria.

Assim, em termos da trajetória da pesquisa de recepção, sua narrativa depende dos diferentes ângulos propostos por diversos historiadores do campo, cada qual com uma perspectiva que incluiria, excluiria ou daria maior relevância a certas abordagens, conforme concepções ou filiações teóricas (JACKS; ESCOSTEGUY, 2005); os diversos entendimentos sobre audiência e seus processos de recepção também são tributários de enquadramentos e desenvolvimentos teóricos distintos, que poderiam levar a um terceiro elemento, ou seja, o papel da pesquisa no tensionamento das teorias tanto a partir das transformações internas do campo quanto das socio-histórico-culturais e comunicacionais (LOPES, 1990).

Tomada em sentido amplo, ou seja, a recepção como o âmbito oposto ao da emissão, poderia ser afirmado que os estudos de comunicação, como entendemos hoje, são fundados pela problemática da "recepção". Isto é, pela preocupação com o que os meios de comunicação da época poderiam estar causando na audiência, propósito da teoria dos efeitos que começa a ser desenvolvida entre os anos 1920 e 30, no cenário da sociologia norte-americana.

Identificada usualmente como communication research, esta tradição praticamente inaugura a perspectiva da relação das pessoas com os meios, mesmo que o foco estivesse no poder destes sob o ponto de vista da propaganda política e da publicidade. 0 termo recep-

\footnotetext{
${ }^{1}$ Neologismo espanhol criado para fazer paralelismo com ouvidoria.
} 
ção nasce neste contexto, seguindo o modelo publicado em $1948^{2}$ por Harold Lasswell, emissor - mensagem - meio - receptor - efeito, enunciado através da fórmula "quem, diz o que, em que canal, para quem, com que efeito?".

Este modelo foi corroborado por outro muito similar, embora vindo da área da matemática e a serviço da teoria da informação, proposto logo depois, em 1949, por Shannon e Weaver. Como comenta Mauro Wolf (1987, p. 18), “[...] há alguns modelos de pesquisa que se desenvolveram e enraizaram simultaneamente 'contaminando-se' e 'descobrindo-se' reciprocamente, acelerando ou modificando o desenvolvimento global do sector.".

Ambos foram antecedidos pela chamada teoria da agulha hipodérmica ${ }^{3}$ e tiveram uma grande influência na pesquisa em comunicação, e em certos aspectos ainda têm, consolidando, como consequência, o termo recepção. Passadas tantas décadas, o termo ainda não foi superado, embora muito criticado por estar tão intrinsecamente vinculado a uma perspectiva que centraliza o poder no âmbito dos meios.

Sem uma solução adequada para designar tudo que envolve este processo de relação com os meios, houve, e seguem as tentativas de cunhagem de termos que designem tudo isto de forma mais coerente com perspectivas mais abertas que se desenvolveram a partir daí, mesmo no próprio âmbito da communication research.

Ainda na década de 1970, o canadense Jean Cloutier (1975) ${ }^{4}$ propôs o termo EMIREC (emissor+receptor) no escopo do quarto episódio ${ }^{5}$ de uma história da comunicação, proposto por ele como o da self-media, a qual para a época seria a fotografia, gravadores de som e imagem, fotocópias, etc., ao que contemporaneamente poderia ser agregado o computador e a internet.

Sem seguir uma cronologia e muito menos buscando recuperar todas as tentativas de nomeação da relação das audiências com os meios, comenta-se que Guillermo Orozco (1996), estudando o contexto especificamente televisivo, cunhou o conceito de televidência, o qual abrangeria todo o processo constitutivo e histórico desta relação, e mais recentemente o de comunicantes para expressar a interação do receptor com os meios em regime de convergência. Diz o autor que

[...] há que se reconhecer que a tendência dos comunicantes ${ }^{6}$ contemporâneos é a de deixar de serem audiências definidas pelos modos

\footnotetext{
${ }^{2}$ Segundo Wolf (1987, p. 24), o modelo já existia nos anos 1930.

${ }^{3}$ Segundo Chaffe e Hochheimer (Apud Wolf, 1994), esta teoria não é científica e seria uma não-tradição.

${ }^{4} \mathrm{O}$ original é de 1973.

${ }^{5} \mathrm{O}$ primeiro episódio seria a comunicação interpessoal, o segundo a comunicação de elite realizada através da escola e o terceiro a comunicação de massa (Cloutier, 1975).

${ }^{6} \mathrm{O}$ autor nomeia de comunicantes os receptores no contexto da convergência midiática.
} 
de estar como receptores da comunicação, para serem em função dos modos de atuar como usuários e emissores na produção comunicativa, onde a criação e a interatividade predominam. (OROZCO, 2011, p. 394, tradução nossa).

Outro termo em circulação atualmente é prosumer, cuja autoria é reputada a Alvin Toffler (2007), que o cunhou na década de 1980, mas que também carrega um pecado original por plasmar a relação com o mercado ao amalgamar as palavras produtor e consumidor. Este neologismo foi antecedido pelo uso do termo consumidor, que é outra possibilidade de nomeação dos sujeitos envolvidos na relação com a mídia, entre outros tipos de ofertas simbólicas, nomenclatura proposta pela perspectiva dos estudos de consumo cultural, que estuda esta relação em um âmbito mais amplo. Consumidor e receptor são termos que tendem a ser usados de modo intercambiável, embora haja tentativas de diferenciar os processos e práticas a que se referem.

Entre os brasileiros, houve algumas tentativas de renomear o fenômeno da recepção: João Luis Tilburg (1994) ensaiou o termo "interlocutoriedade", Mauro Wilton de Sousa (1998) chama "práticas de recepção", e no âmbito latino-americano surgiu, na década de 1970, a expressão recepção crítica para matizar a natureza do termo original, rebatizando a expressão recepção ativa, que já circulava em outros entornos acadêmicos.

Ainda com a manutenção do termo recepção, segundo Orozco (2012), têm circulação atualizada expressões como "recepção hiperativa" e "interativa", ou ainda "mutante", referindo-se aos modos contemporâneos de atuação junto à mídia.

A situação hoje é mais pungente diante da convergência midiática, o que reforça a necessidade de cunhagem de novo(s) termo(s), mais adequado(s) e ao mesmo tempo com plasticidade capaz de vencer a força semântica do termo "recepção", que diz tudo ou quase tudo sobre o que está sendo referido, sendo que agora há necessidade de incluir a participação mais efetiva do receptor no âmbito da produção.

Há outras tentativas, por exemplo, a explorada no circuito do trabalho desenvolvido pelo Observatório Ibero-Americano da ficção televisiva (OBITEL), onde a recepção está sendo adjetivada com o acréscimo do termo transmidiática. Assim, recepção transmidiática tem clara relação com as proposições de Henry Jenkins (2008), que trata com centralidade da transmedia storytelling, ou seja, da produção ficcional transmidiática, tributária da convergência midiática. 
Tomando este contexto, Jenkins propõe chamar os receptores de fãs, pois é neste nível que se estabelece a relação com a ficção televisiva, efetivada de diversas formas, que pode ir da simples interação à produção ficcional parodiando ou recriando o produto de referência.

Nas pesquisas desenvolvidas pelo OBITEL, a questão aparece no Anuário de 2010 Convergências e transmidiação da fiç̧ão televisiva, a qual é aprofundada no ano seguinte, no Anuário 2011 - Qualidade na ficção televisiva e participação transmidiática das audiências, explorando- a como temática do ano. Ou seja, estudar telenovela - ou, de fato, qualquer outro produto midiático -, não é mais possível sem levar em conta os "efeitos" da mobilidade, portabilidade, multimidialidade, hipertextualidade e interatividade que levam à participação da audiência nas próprias estratégias da produção ou para além delas (AQUINO, 2012).

Como consequência, além de considerar as alterações das lógicas de produção, no mínimo há que se reconhecer que existe um consumo ampliado ou, idealmente, um consumo produtivo - nos termos de Calabrese (19997 apud OBITEL, 2010) -, para identificar quando há efetiva participação da audiência na criação ou produção midiática. Talvez aqui coubesse o termo prosumers/ prossumidores, ainda que com problemas de procedência, uma vez que está tratando-se de consumo midiático, e não exatamente de recepção, o que é operacionalmente interessante distinguir.

Embora não haja consenso na área, pode-se considerar que se trata de duas instâncias diferentes de análise, uma mais genérica em relação aos meios de comunicação e outra mais focada em processos interpretativos, referentes aos seus conteúdos.

No primeiro caso, enfatiza-se seu entendimento como estudos da ordem da relação mais ampla com os meios de comunicação, sua presença no cotidiano pautando tempos, espaços, relações, percepções etc. No caso dos estudos de recepção, trata-se de detalhar aspectos do fenômeno midiático na dimensão de seus conteúdos, fechando o foco de observação, o que não significa dispensar uma análise do consumo midiático para adentrar nas práticas dos receptores. (TOALDO; JACKS, 2013, p. 8) ${ }^{8}$.

Voltando à noção de recepção transmidiática, o que ela traz de diferente e que finalmente promove, por força da convergência, é a necessidade de ultrapassar analiticamente as relações monomidiáticas das audiências. Ou seja, trata-se da trama midiática estabelecida pela circulação concomitante e ininterrupta dos conteúdos de todos os meios presentes em um contexto social e o fluxo criado pelos próprios receptores a partir deste fluxo midiático,

\footnotetext{
${ }^{7}$ CALABRESE, O. A idade neobarroca. Lisboa: edições 70.

${ }^{8}$ Ambos podem ser realizados sem a complementação do outro, pois atendem a questões distintas, mas os estudos de recepção podem se valer do consumo midiático como preâmbulo para conhecer as preferências e envolvimentos mais profundos do público estudado, para a partir daí investir em um estudo de recepção.
} 
constituindo um superfluxo conforme propõe Klaus Jensen (1997). Isso já se efetivava com anterioridade ao processo de convergência, mas, mesmo assim, os estudos em geral isolavam um ou outro meio para ser estudado. Hoje isto é impossível, pois todos os meios estão vinculados e conectados via internet, e o receptor tem ampliada a potencialidade de construção de seu fluxo particular e/ou coletivo, considerando que muito do que é consumido se dá através das redes sociais digitais. "Audiências em redes" tem sido a denominação utilizada para analisar o modo coletivo como se desenha hoje a atuação dos receptores.

Ainda sobre as novas tentativas de renomear os processos e as práticas dos receptores, o dinamarquês Kim Schrøder está denominando o mesmo fenômeno como audiência crossmidiática (2011), em outros termos, de recepção crossmidiática, e também afirma que não é uma questão de opção enfocar a convergência, mesmo que o interesse seja em um ou outro meio. É uma determinação da nova realidade midiática e comunicacional que força o pesquisador a extrapolar sua visão sobre um único meio e explorar as convergências com outros meios e conteúdos para poder entender esta nova forma de ser audiência.

Essas terminologias e noções atendem às novas configurações midiáticas, mas não servem para trabalhar indistintamente fenômenos como o "cross" e o "trans" midiático. 0 primeiro é mais amplo e antigo, a publicidade mesmo já lidava com estas estratégias de produção e veiculação que se utiliza de vários meios para divulgar a mesma mensagem ou variações dela; o segundo se trata, na explicitação de Jenkins (2008), de uma estratégia mais ousada, a mensagem complementa-se pela utilização de vários suportes e depende da participação do receptor para se efetivar.

Por outro lado, à tendência conhecida como midiatização, onde há uma exacerbação dos fluxos e circulação de conteúdos dos meios de comunicação, Guillermo Orozco opõe outra que chama de audienciação (2006). Esta noção dimensiona a constituição dos sujeitos sociais na relação com o papel hegemônico dos meios, afirmando o autor que, apesar de toda a transformação atual nas práticas de recepção, continuamos como audiência de grandes e pequenas telas, metáfora utilizada por ele para se referir à relação com a mídia. Este é um atributo central da identidade social hoje, por isso ele propõe um sentido amplo para o termo audiência, na intenção de nomear a experiência frente a um mundo mediado pelos meios e tecnologias de comunicação, isto segundo ele "[...] independentemente do tipo de interação que se estabeleça com as telas, mais ativa ou mais passiva, mais crítica ou mais conformista, mais determinada pela Recepção do que pela emissão ou vice-versa [...]." (OROZCO, 2012, p. 43, tradução nossa). 
A participação das audiências diante das transformações tecnológicas, recolocando em evidência a importância da instância da recepção para os estudos de comunicação, simultaneamente faz o mesmo para os próprios estudos de recepção, pois estas transformações borram as fronteiras entre emissão e recepção, obrigando a teoria e a pesquisa a se reposicionarem para entender o que está ocorrendo com a interação e aproximação destas duas instâncias dos processos e práticas de comunicação.

Assim, as metáforas do chip e da agulha servem para sinalizar o desenvolvimento das teorias $^{9}$ da comunicação. Elas começam interessadas pelos efeitos dos meios massivos e hoje tematizam as profundas mudanças sociais e culturais, as quais devem ser centrais na busca da compreensão dos fenômenos comunicacionais e culturais pelas quais passam a humanidade, cada vez mais perpassados pela imbricação entre as esferas midiáticas.

\section{Finalmente, "la recepción ya no alcanza": considerações transitórias.}

A expressão acima, em espanhol, como no texto original, foi cunhada no início da década de 1990 pelo argentino Sérgio Caletti (1992), em um artigo que exibia esta afirmação como título. Tomaram-na como motivação para exercer críticas aos estudos de recepção; dentre os autores das mais conhecidas, subsequentemente, Cláudia Herrán (1994), Alejandro Grimson e Mirta Varela (1999), Ana Carolina Escosteguy (2009), Florencia Saintout e Natália Ferrante (2011).

Os referidos autores teceram suas críticas em contextos e momentos diferentes, para tematizar aspectos também diferentes, como discordância com modelos analíticos e procedimentos metodológicos, aspectos políticos da pesquisa, insuficiências analíticas, despolitização das análises, abandono do contexto das culturas populares, etc.

Cláudia Herrán (1994) utiliza a expressão de Caletti para problematizar o salto qualitativo não dado pelos estudos de recepção, tendo como foco os latino-americanos, em especial o modelo de Orozco, que segundo ela, e com base na crítica do autor argentino, precisava ultrapassar o estudo das mediações para chegar aos sentidos. 0 foco desta crítica está no nível epistemológico, ressaltando que não houve rupturas em relação aos paradigmas anteriores, em especial os que tratavam dos efeitos dos meios.

\footnotetext{
${ }^{9}$ Elas estão detalhadas em diversos textos de referência: Five traditions in search of the audience, de Jensen e Rosengreen (1990); Los efectos sociales de los media (1994) e Teorias da comunicação (1987) de Mauro Wolf; Teorias de la comunicación de Miguel Moragas (1981); Sociología de la comunicación y de los medios de Éric Maigret (2005), entre tantos outros. No Brasil: Efeito e recepção de Itânia Gomes (2004); Comunicação e Recepção de Nilda Jacks e Ana Carolina Escosteguy (2005); Teoria da comunicação de Luís Sá Martino (2009), entre alguns outros.
} 
Herrán (1994, p. 52, tradução nossa) diz que isso tem a ver com as pesquisas que tratam de casos muitos específicos que não avançam na direção do contexto social e

[...] ficam muitas vezes neste aspecto micro, sem proporcionar pistas que nos permitam incrustar estes processos comunicativos nos sistemas simbólicos globais geradores de sentido social. Enquanto os estudos comunicativos não chegarem mais adiante, serão estudos demasiado focalizados e restritos.

Grimson e Varela (1999) utilizam a crítica de Caletti para problematizar a pesquisa de recepção em solo argentino nos anos 1980, década que identificam como de consolidação desta abordagem de pesquisa, consolidação esta alavancada pela discussão que se dá em toda a América Latina. Os autores enfatizam especialmente a crítica que ele faz ao que chama de "recepcionismo", ou seja, a pesquisa da área:

[...] havia se convertido de um programa de investigação estimulante em uma 'ideologia da recepção' que tendia a converter as perguntas em respostas, a contribuição a uma nova visão sociocultural da vida contemporânea em paradigma de análise comunicacional [...]. (GRIMSON; VARELA, 1999, p. 83, tradução nossa).

Escosteguy (2009), por sua vez, em sua principal crítica aos estudos de recepção, ancorada na afirmação de Caletti, comenta que:

[...] o espaço da produção, o resultado das práticas aí localizadas, isto é, o texto midiático, e o espaço da recepção não mereceram uma atenção equilibrada na grande maioria das pesquisas brasileiras. As condições de produção raramente fizeram parte desses estudos e mesmo o próprio texto é bastante negligenciado em tais investigações [...]. (ESCOSTEGUY, 2009, p. 1-15).

Neste sentido, a autora indaga sobre como a pesquisa poderia preservar a dinâmica e particularidades do processo comunicativo, partindo dos atores sociais inseridos em determinadas condições sociais concretas e sem perder de vista as tecnologias de comunicação que saturam a vida social e cultural contemporânea. Esta não é uma questão nova, a própria autora admite, e seu esforço é para enfatizar a necessidade de tirar do âmbito estrito dos receptores o entendimento dos processos de recepção que não prescindem do entendimento do âmbito midiático, seguindo a tendência da crítica que se efetiva desde o início dos anos 2000.

Por fim, Florencia Saintout e Natalia Ferrante (2011), ao criticarem o estado atual das pesquisas de recepção na Argentina, também retomam o artigo de seu conterrâneo para sustentar sua argumentação. 0 principal argumento é a despolitização dos estudos que per- 
deram sua capacidade crítica, aspecto considerado como o mais marcante da pesquisa de comunicação naquele país. Em suas palavras:

[...] o que sucede agora nos estudos contemporâneos poderia assinalar-se como um esquecimento da estrutura e do poder em prol da ênfase da vida cotidiana, de atores que parecem situar-se sem relação com a estrutura do espaço social, não porque se desconheça que ela exista, mas porque simplesmente não se trabalha a articulação com ela. Cremos que as condições do fazer investigativo, mas fundamentalmente a forte presença de uma vertente dos estudos culturais, às vezes demasiado sensíveis à perspectiva neoliberal e pós-moderna, poderiam explicar parte do que sucede [...]. (SAINTOUT; FERRANTE, 2011, p. 34, tradução nossa).

Apesar deste tipo de críticas - em busca do aprofundamento do próprio processo de pesquisa -, e decorridas quase duas décadas da publicação do artigo em pauta (que se refere especificamente ao contexto latino-americano), o campo mostrou que Sérgio Caletti foi precipitado ou visionário, uma vez que o desenvolvimento e a consolidação desta área de pesquisa tardaram pelo menos mais uma década, e só recentemente essa começa a dar sinais de insuficiência, por conta do novo contexto tecnológico.

Assim, para fazer justiça com a perspectiva dos estudos de recepção (nas suas diversas alternativas teóricas e metodológicas), os quais abriram a análise para a complexidade que envolve os processos e práticas de comunicação ao extrapolarem os tradicionais enfoques nos meios e mensagens, âmbitos necessariamente parciais, talvez apenas agora tenha chegado a hora de dizer "a recepção já não alcança".

O motivo, entretanto, não tem nada a ver com as premissas das autoras citadas anteriormente, embora em alguma medida possam ser entendidas suas críticas quando apontam para a fragilidade metodológica de certos estudos, a desatenção a certas prerrogativas teórico-empíricas a serem seguidas, a falta de diálogo com outras áreas que se interseccionam com os fenômenos da comunicação, entre outras críticas.

Agora, o motivo para tal afirmação é devido às novas relações estabelecidas entre meios e audiências frente aos processos de convergência midiática. 0 embaralhamento de processos e práticas que envolvem os tradicionais âmbitos da produção e da recepção, ainda que isso não se aplique a todos, dificulta a utilização da mesma noção de recepção e mesmo do termo, além de parte dos pressupostos conceituais que orientam esta perspectiva de estudos, como os que dizem respeito a maior dependência do âmbito da recepção ao da emissão.

Além do mais, a tendência dos estudos de recepção de centrarem-se na análise de um meio ou de alguns poucos, de um gênero ou programas específicos, pode cegar a visão dos 
mais amplos processos que configuram as práticas midiáticas dos receptores, hoje em um dimensionamento nunca experimentado antes.

Por isto, só agora podemos lançar mão plenamente da expressão "a recepção já não alcança", mas para indicar outra coisa: que o entendimento dos processos e das práticas comunicativas ganhou ainda maior complexidade, pois na atualidade os conteúdos de novas e velhas mídias se tornaram híbridos, reconfigurando a relação entre as tecnologias, indústria, mercados, gêneros e públicos. Isto porque ocorre um cruzamento entre a mídia massiva e não massiva, que são assistidas em múltiplos suportes, às vezes simultaneamente, caracterizando a era da convergência midiática.

O fluxo de conteúdo que perpassa múltiplas plataformas e mercados midiáticos acontece, sobretudo, pelo comportamento migratório percebido no receptor, que oscila entre diversos veículos e meios em busca de experiências diferenciadas de entretenimento, informação e interação social. Logo, a convergência também é caracterizada pelo seu aspecto cultural, abarcando uma nova configuração que ultrapassa o âmbito da produção e do produto midiático. Hoje a recepção já não é um processo de mão única em se tratando do fluxo de participação e mesmo de produção de conteúdos, o que, aliás, em outros aspectos, como a produção simbólica, nunca o foi.

A ascensão da chamada cultura participativa foi possibilitada principalmente pela Internet e pelas tecnologias digitais, especialmente após a chamada Web 2.0. Segundo O’Reilly (2005), responsável pela popularização do termo Web 2.0, essa segunda geração da web parte da premissa de que os sistemas evoluem na medida em que mais pessoas os utilizam e contribuem para o seu melhoramento. Por isso, uma das características mais marcantes da Web 2.0 é a sua "arquitetura amigável", que não exige dos internautas conhecimentos técnicos profundos para a participação e a produção de conteúdo, possibilitando o surgimento de um ambiente colaborativo em rede. A Web 2.0 propicia “[...] repercussões sociais importantes, que potencializam processos de trabalho coletivo, de troca afetiva, de produção e circulação de informações, de construção social de conhecimento apoiada pela informática." (PRIMO, 2007, p. 1-2).

Esta cultura participativa, que não nos permite mais conceber os produtores e consumidores de mídia como figuras distintas, desempenhando diferentes papéis - representa um dos conceitos-chave para entender a convergência (JENKINS, 2008) ${ }^{10}$. Por outro lado, se o

\footnotetext{
${ }^{10}$ Dentro desse contexto, uma das esferas corresponde a dos fãs, a qual tem ganhado importância para a compreensão do processo de convergência, já que, segundo Jenkins (2008), os fãs são os consumidores mais valiosos para a indústria, pois além de serem ex-
} 
computador pessoal "transformou todas as pessoas em produtores e editores", Anderson afirma que foi a internet que "converteu todo mundo em distribuidores" (2006, p. 53), fazendo com que mercados de nicho, como as produções de fãs, se tornassem uma potência econômica tão lucrativa quanto as indústrias tradicionais.

Jenkins cita como exemplo os fãs de Guerra nas Estrelas (Star Wars) que, utilizando tecnologias digitais, são capazes de produzir filmes amadores tão bons que a própria indústria do entretenimento viu-se obrigada a acompanhar de perto essas produções a fim de não perder o controle sobre sua propriedade intelectual. A partir de então, afirma Jenkins, as indústrias passaram a adotar dois tipos de postura em relação às produções amadoras: proibicionista, regulando e criminalizando muitas formas de participação dos fãs, e cooperativis$t a$, tratando os “[...] fãs como colaboradores importantes na produção de conteúdos, e intermediários alternativos, ajudando a promover a franquia." (2008, p. 184).

Falar de convergência implica, também, levar em consideração o atual contexto de acesso móvel a web, por meio de aparelhos que possuem convergência de funções. 0 acesso à web não se faz apenas de modo isolado, de dentro de um escritório, mas sim em qualquer lugar, para quem tem condições técnicas e habilidades para estar conectado. As pessoas podem ver televisão, por exemplo, dentro do carro, na rua, no shopping.

A cultura da mobilidade (SANTAELLA, 2007, p. 18) é fruto dos meios de comunicação sem fio, móveis, que falam da presença mediada, telepresença, presença ausente, distância virtual, ubiquidade; todas elas expressões que colocam em questão antigas certezas sobre nossa compreensão do mundo. Constata Santaella que:

Pouco mais de dez anos se passaram desde a consolidação da cibercultura com a explosão da WWW e, hoje em concomitância com o potencial aberto pela Web 2.0, a cultura da mobilidade, uma variação avançada da cibercultura, baseada nos dispositivos móveis, aliados ao sistema de posicionamento global (GPS), já começa a render frutos que têm chamado atenção de artistas e de teóricos e críticos da comunicação e cultura [...] (SANTAELLA, 2007, p. 18).

Como disse Jenkins (2008, p. 8), estamos numa época de grandes transformações, e todos nós temos três opções: temê-las, ignorá-las ou aceitá-las. Diante desse complexo processo de transformação, percebe-se, por exemplo, a crescente tensão entre consumidores e

tremamente fiéis aos produtos midiáticos de sua preferência, prestam mais atenção aos anúncios, tendem a comprar mais e, principalmente, são mais ativamente envolvidos. Fãs criam sites, blogs, comunidades e fóruns de discussão na internet, escrevem narrativas, produzem vídeos e fazem música sobre seus produtos preferidos. Entretanto, como adverte Jenkins, nada disso é novidade: “o que mudou foi a visibilidade da cultura dos fãs. A web proporcionou um poderoso canal de distribuição para a produção cultural amadora. Os amadores têm feito filmes caseiros há décadas; agora esses filmes estão vindo a público." (2008, p. 181). 
indústria, e são “[...] as contendas e as conciliações resultantes que irão definir a cultura pública do futuro [...]." (JENKINS, 2008, p. 51).

Se, por um lado, o receptor em geral está reivindicando o direito de participar efetivamente de sua cultura, e, com as possibilidades abertas pelas tecnologias digitais e a internet, eles adquiriram poder de negociação considerável perante as indústrias tradicionais; por outro lado, essas indústrias estão cada vez mais atentas ao potencial que os consumidores/receptores em geral representam e, ao mesmo tempo em que tentam obter vantagens dessa relação, procuram mantê-la sob seu controle a fim de que seus direitos autorais sejam preservados.

Como não há como dissociar os diferentes âmbitos deste fenômeno, que é complexo, multidimensional e extremamente interconectado, uma possibilidade concreta é seguir a lógica proposta por Jesús Martín-Barbero (1987). Ou seja, entrar aos processos comunicacionais sem descurar dos aspectos estruturais e estruturantes dos meios, chegando a eles justamente pelo percurso dos vínculos estabelecidos pelos fluxos, usos e apropriações dos conteúdos elaborados pelos receptores, como uma estratégia efetiva para desentranhar os novos modos de relação entre meios e audiências.

Isso significa, em última instância, efetivar um movimento articulado de análise tanto dos meios como de seus públicos, através das mediações que os vinculam, que já não são as mesmas, mas como tal continuam exercendo seu papel configurador, justamente porque dependem de fatores estruturais e contextuais que os relacionam.

Também pode ser produtivo seguir a indicação de Fausto Neto quando diz que as novas lógicas são dadas por interfaces, mais do que por contatos e, assim, a circulação sai de uma zona invisível "[...] para transformar-se em dispositivos (com marcas visíveis) sóciotécnico-discursivos que vão reformular imensamente os processos de interação, especialmente o lugar e, o próprio conceito de recepção [...]." (FAUSTO NETO, 2010, p. 63).

0 autor argumenta ainda que a associação do conceito de circulação à noção de dispositivo tem a ver com as profundas alterações tecnológicas que engendram a arquitetura comunicacional atual. Trata-se da expansão do produto midiático através de diferentes plataformas, processo efetivado pela participação ativa dos consumidores/ receptores (respectivamente perseguindo e criando conteúdos por meio de diferentes sistemas de mídia e construindo ou navegando nos fluxos midiáticos existentes), uma espécie de "recepção especializada", o que, em alguma dimensão, é constituída pelos fãs. Por outro lado, os meios para ele: 
[...] instituem, por suas novas feições, zonas complexas de intensos feedbacks entre os atores removendo posições, redefinindo protocolos de comunicação, estabelecendo novas concepções e natureza de vínculos, alterando espacialidades e temporalidades sobre as quais se funda o ato comunicativo [...] (FAUSTO NETO, 2010, p. 63).

Assim, em termos da pesquisa, em uma instância, é necessário pensar os espaços de circulação e fluxos de consumo, que nesse panorama envolvem a interatividade, a participação e o encadeamento midiático (PRIMO, 2008), potencializados pela configuração da web 2.0, e a nova cultura de acesso, propiciada pela mobilidade, atentando para as táticas de apropriação, reconfiguração, produção e interação dos públicos; em outra instância, é necessário não descurar de que tudo isto acontece em contextos culturais mais amplos e tradicionais, que na frente da tela há um receptor que vive em outras esferas institucionais, as quais também configuram suas práticas on line.

Desta forma, pode-se recuperar os caminhos da circulação de produtos e mensagens e seus fluxos, para posteriormente indagar sobre o que estas marcas tem a ver com os usos e apropriações dos receptores, que seguramente estão permeados por práticas no mínimo híbridas, em termos de sua origem analógica e digital, sem contar com as práticas culturais mais tradicionais.

Para terminar este rápido reexame da trajetória dos estudos de recepção, assim como da nomenclatura e noções que plasmaram a discussão em torno do assunto, empresta-se de Orozco (2011) sua visão sobre o que testemunhamos hoje na área. Para ele trata-se de um momento de transição muito importante que deve ser compreendido a partir do que ele chama de "epistemologia do trânsito", que nem deve desconhecer a centralidade da comunicação mediada por tecnologias digitais - autocomunicação massiva (Castells) -, nem a permanência de velhas tecnologias midiáticas massivas, embora reconhecidamente elas estejam cada vez mais imbricadas. Segundo ele

É precisamente com um entendimento nesta direção, do analógico ao digital, que se podem aproveitar os conhecimentos e resultados de investigações anteriores com as velhas telas, e conectar para explicar de maneira mais realista o que sucede com as novas. Tudo sob o entendimento que seguimos sendo audiências, trocando papéis, mas sempre em relação com as telas, que é o que caracteriza tal categoria [...]. (OROZCO, 2011, p. 390, tradução nossa). 


\section{Referências}

ALSINA, Miquel Rodrigo. Los modelos de la comunicación. Madrid: Tecnos, 1995.

ANDERSON, Chris. A cauda longa: do mercado de massa para o mercado de nicho. Rio de Janeiro: Elsevier, 2006.

AQUINO, Maria Clara. Convergência entre televisão e web: proposta de categorização analítica. 2012. Tese (Doutorado em Comunicação e Informação) - Programa de PósGraduação em Comunicação e Informação, Universidade Federal do Rio Grande do Sul, Porto Alegre, 2012.

CALETTI, Sergio. La recepción ya no alcanza. In: CORTÉS, Carlos Luna; SOLIS, Beatriz; NUÑEZ, Luis (Org.). Generación de conocimientos y formación de comunicadores. Colômbia: FELAFACS, 1992.

CLOUTIER, Jean. A era de emirec ou a comunicação áudio- scripto-visual na hora dos self-media. 2. ed. Lisboa: Ministério da Educação e Investigação Científica, Instituto de Tecnologia Educativa, 1975.

ESCOSTEGUY, Ana Carolina. Anotações para pensar o sujeito nos estudos culturais. Animus, Santa Maria, v. 2, n. 1, p. 69-79, 2003.

ESCOSTEGUY, Ana Carolina. Quando a recepção já não alcança: os sentidos circulam entre a produção e a recepção. E-COMPóS, Brasília, v. 12, n.1, jan./abr. 2009.

FAUSTO NETO, Antonio. As bordas da circulação. ALCEU, Rio de Janeiro, v. 10, n. 20, p. 5569. jan./jun. 2010.

GOMES, Itania Maria Mota. Efeito e recepção: a interpretação do processo receptivo e duas tradições de investigação sobre os media. Rio de Janeiro: E-Papers, 2004.

GRIMSON, Alejandro; VARELA, Mirta. Audiencias, cultura y poder: estudios sobre televisión. Buenos Aires: EUDEBA, 1999.

HERRÁN, Claudia. Un salto no dado: de las mediaciones al sentido. In: OROZCO, Guillermo. Televidencia: perspectivas para el análisis de los procesos de recepción televisiva (Org.). Ciudad de México: Universidad Iberoamericana, 1994. (Cuadernos de comunicación y prácticas sociales, n. 6).

JACKS, Nilda; ESCOSTEGUY, Ana Carolina. Comunicação e recepção. São Paulo: Hacker, 2005.

JENKINS, Henry. Cultura da convergência. São Paulo: Aleph, 2008.

JENSEN, Klaus Bruhn; ROSENGREN, Karl. Five traditions in search of the audience.

European Journal of Communication, v. 5, n. 2/3, p. 207-38, 1990. 
JENSEN, Klaus Bruhn. La Semiótica Social de la Comunicación de Masas. Barcelona: Bosch, 1997.

LOPES, Maria Immacolata Vassalo de. Pesquisa em Comunicação. Formulação de um modelo metodológico. São Paulo: Loyola, 1990.

LOPES, Maria Immacolata; OROZCO, Guillermo (Org.). Convergências e transmidiação da ficção televisiva: OBITEL 2010. São Paulo: Globo, 2010.

LOPES, Maria Immacolata. Qualidade na ficção televisiva e participação transmidiática das audiências: OBITEL 2011. São Paulo: Globo, 2011.

MAIGRET, Éric. Sociología de la comunicación y de los medios. Bogotá: Fondo de Cultura Económica, 2005

MARTÍN-BARBERO, Jesús. De los medios a las mediaciones: comunicación, cultura y hegemonía. México: Gustavo Gilli, 1987.

MARTINO, Luis Mauro Sá. Teoria da Comunicação: idéias, conceitos e métodos. Petrópolis: Vozes, 2009.

MORAGAS, Miguel de. Teorías de la comunicación. Barcelona: Gustavo Gilli, 1981.

O`REILLY, Tim. What is web 2.0: design patterns and business models for the next generation of software. 2005. Disponível em: <http://www.oreillynet.com/lpt/a/6228>. Acesso em: 22 fev. 2010.

OROZCO, Guillermo. Televisión y audiencias: un enfoque cualitativo. Madrid: Ediciones de la Torre, 1996.

OROZCO, Guillermo. Comunicação social e mudança tecnológica: um cenário de múltiplos desordenamentos. In: MORAES, Dênis de. (org.). Sociedade Midiatizada. Rio de Janeiro: Mauad, 2006.

OROZCO, Guillermo. Televisión y producción de interacciones comunicativas. In: Comunicación y Sociedad, Guadalajara, n. 18, p. 39-54, jul./dic. 2012.

OROZCO, Guillermo. La condición comunicacional contemporánea. Desafíos latinoamericanos de la investigación de las interacciones en la sociedad red. In: JACKS, Nilda et al. Análisis de recepción en América Latina: un recuento histórico con perspectivas al futuro. Quito: CIESPAL, 2011.

PRIMO, Alex. 0 aspecto relacional das interações na Web 2.0. E-Compós, Brasília, v. 9, p. 121, 2007.

PRIMO, Alex. A cobertura e o debate público sobre os casos Madeleine e Isabella: encadeamento midiático de blogs, Twitter e mídia massiva. Galáxia, São Paulo, v. 16, 2008. 
RINCÓN, Omar. No más audiencias, todos devenimos productores. Comunicar: revista científica iberoamericana de comunicación y educación, Andalucía, v. 15, n. 30, mar. 2008.

SAINTOUT, Florencia, FERRANTE, Natália. La recepción no alcanzó: aportes para pensar una nueva agenda de comunicación. In: JACKS, Nilda et al. (Org.). Análisis de recepción en América Latina: un recuento histórico con perspectivas al futuro. Quito: Quipus, CIESPAL, 2011.

SANTAELLA, Lucia. Linguagens líquidas na era da mobilidade. São Paulo: Paulus, 2007.

SCHRØDER, Kim C. Audiences are inherently cross-media: audiences studies and the crossmedia challenge. Centar za usmeravanje komunikacija. n.18. 2011.

SHANNON, Claude; WEAVER, Warren. The mathematical theory of communication. Urbana: University of Illinois, 1949.

SOUSA, Mauro Wilton de. A recepção sendo reinterpretada. Novos Olhares: revista de estudos sobre práticas de recepção a produtos mediáticos, v. 1, n. 1, 1998.

TILBURG, João Luis van. Televisão e audiência. In: FAUSTO NETO, Antonio; BRAGA, José Luis; PORTO, Sérgio. Brasil: comunicação, cultura e política. Rio de Janeiro: Diadorim, 1994.

TOALDO, Mariângela; JACKS, Nilda. Consumo midiático: uma especificidade do consumo cultural, uma antessala para os estudos de recepção. In: ENCONTRO ANUAL DA COMPÓS, 22., Salvador, 2013. Anais... Salvador: Universidade Federal da Bahia, 2013. Disponível em: <http://www.compos.org.br/data/biblioteca_2115.pdf>. Acesso em: 21 ago. 2015.

TOFFLER, Alvin. A terceira onda. São Paulo: Record, 2007.

WOLF, Mauro. Los efectos sociales de los media. Barcelona: Paidós Ibérica, 1994.

WOLF, Mauro. Teorias da comunicação. Lisboa: Editorial Presença, 1987. 


\title{
From the needle to the microchip: a brief review of reception studies
}

\begin{abstract}
This study reviews the trajectory of reception studies to point out the narrative character of such theories, depending on the point of view of the narrator. There are theoretical and ideological linkages, which result in different ways of conceiving the history of the field, with distinctive inclusions and exclusions of theories and trends that vary from author to author over time. Nomenclatures which entered the field from the the beginning of its activities, in the early years of the last century are indicated - a critical factor in this moment of transition of the status of the receptor, which, in many cases, becomes a producer, a producer-receiver. We present some of the criticism regarding the scope of reception studies to understand the contemporary communication processes, which have reached a high degree of complexity. The study is closed with some possibilities of analytical confrontation that arise from the very tradition of the reception studies anchored in cultural studies, with possible arrangements with cybercultural studies.
\end{abstract}

\section{Keywords}

Reception studies. Communication theory. Cultural Studies.

Recebido em 25/08/2015

Aceito em 25/11/2015 